\title{
Living in Limbo: Iraqi Refugees in Indonesia
}

\author{
Sue Hoffman
}

\begin{abstract}
Between 1999 and 2001 about 4,800 Iraqi refugees made their way to Australia. While the vast majority reached their destination, some never got that far, instead finding themselves stranded in Indonesia for up to 10 years. The author conducted interviews with Iraqi refugees in both Indonesia and Australia, from which a number of themes emerged. Central to these was the insecurity and uncertainty faced by participants over a protracted period with a marked difference when comparing the narratives of the participants settled in Australia with those living in a limbo situation in Indonesia. The former recalled the stresses of their journey and the associated feelings of fear, anxiety, and depression. In the case of the latter group, these feelings were ever present as their journey was not yet over.
\end{abstract}

\section{Résumé}

C'est au nombre de 4800 que des réfugiés irakiens se sont installés en Australie entre 1999 et 2001. Alors que la majorité de ce nombre ont atteint leur destination, certains ne se sont jamais rendus et se sont retrouvés bloqués en Indonésie pendant une période allant jusqu'à 10 ans. L'auteur a effectué des entrevues avec des réfugiés irakiens en Indonésie et en Australie, et un certain nombre de thèmes se sont dégagés. Un des thèmes centraux est l'insécurité et l'incertitude des réfugiés confrontés à un séjour prolongé, ainsi que le contraste marqué entre les récits des réfugiés installés en Australie, et de ceux coincés en Indonésie. Alors que les réfugiés installés en Australie avaient enfin la possibilité de digérer le stress du voyage et les sentiments associés de peur, d'anxiété et de dépression, ces derniers, bloqués en Indonésie subissaient ces mêmes sentiments quotidiennement comme si leur voyage n'était pas encore terminé.

\section{Introduction}

Between 1999 and 2001 an estimated 4,800 Iraqis transited Indonesia, leaving on smugglers' boats bound for Australia. However a few hundred did not make that final leg of their journey and found themselves living in a limbo-like situation for up to 10 years in Indonesia. Initially incarcerated in Indonesian immigration detention centres, they were later released to live in the community. However, without work rights, their day-to day-living arrangements were dependent upon agreements made between the Indonesian government, the Australian government, United Nations High Commissioner for Refugees (UNHCR), and the International Organization for Migration (IOM), rendering the Iraqis largely powerless in making even the most basic decisions about their lives and futures.

In 2006 and 2007, as part of my doctoral research which examined the journeys of Iraqi refugees from the Middle East to Australia, I interviewed Iraqi refugees in both Australia and Indonesia. ${ }^{1}$ The absence of research focused on refugee journeys from the Middle East across southeast Asia was an important consideration in deciding to use interview and analysis methods influenced by grounded theory. Grounded theory contrasts with other research methods which typically require the researcher to decide upon the main focus of the study and review the literature before gathering and analyzing data. This can be problematic when the study concerns a social phenomenon for which there is minimal literature available. Adopting a grounded theory approach means the central theme of the research is decided upon after conducting initial interviews during which the participants identify what they regard as important and significant. Analysis of early interviews then influences decisions by the researcher about the selection of 
further participants, the subjects canvassed in later interviews, and the overall direction of the research. ${ }^{2}$

For these reasons, grounded theory is particularly wellsuited to studies such as mine where there has been little previous research or literature to draw on. Consistent with a grounded theory approach, rather than preparing detailed questions for participants to answer, I invited study participants to tell the story of their journey from Iraq in whatever way they chose. As well as providing them with the opportunity to talk about what they regarded as important and significant, it was consistent with a major aim of my research which was to centre the refugee voice.

I drew upon two main bodies of sociological theory concerned with risk to interpret and analyze the circumstances of participants. Ulrich Beck presents a view of the modern world that "is increasingly occupied with debating, preventing and managing risks that it itself has produced." ${ }^{3}$ Beck argues that decisions made in one era can have unexpected consequences for future generations which are unbounded by time or national borders, and that such hazards typically have the most devastating impact upon the poor and vulnerable who are least able to insure or protect themselves against risk. Obvious parallels can be drawn between Beck's theory and the refugee issue, where conflicts and regimes that give rise to refugees have their origins in decisions made in previous decades. This is particularly apposite with regard to Iraqis. After the First World War and the break-up of the Ottoman Empire, the League of Nations gave the British the mandate over Mesopotamia, which was renamed Iraq after some adjustments to borders to suit colonial interests. Although the mandate formally ended in 1932, many Iraqis considered British involvement in their affairs to have finished only when the British-installed monarchy was overthrown in 1958, which was coincidentally the year Saddam Hussein joined the Ba'ath party. ${ }^{4}$

Beck drew attention to the distinction between "risk decision makers and those who have to deal with the consequences of decisions of others." ${ }^{5} \mathrm{He}$ also made reference to the power imbalance between them; powerful actors minimize the risk to themselves while increasing the risk to others. The power differential is readily apparent when considering the situation for refugees who flee their country of origin when their own government is unwilling or unable to afford them safety and security. They are then obliged to prevail upon other countries from a position of no or limited legal rights and hence vulnerability. In this case the balance of power is clearly weighted in favour of national governments who have the sovereign power to grant or deny them refuge.

From a different perspective, risk is regarded as a technology by which social problems can be managed. This approach has its origins in the work of Michel Foucault and the governmentality theorists who developed his ideas. ${ }^{6}$ Foucault distinguished between three modes of exercising authority; sovereignty, discipline, and governmentality. Sovereign power is evident through the exercise of law and military deployment; discipline is the means by which institutions such as prisons, factories, and schools exert power over inmates, workers, and pupils to conform and is achieved through self regulation; and governmentality is concerned with the various mechanisms employed to exercise authority and control populations that extend beyond security forces, laws, and institutions. It relates to the strategies and tactics used to shape and influence the attitudes, beliefs, and behaviours of resident populations. ${ }^{7}$

The state is therefore but one element in a complex array of authorities, organizations and institutions through which power is dispersed. These are Foucault's "apparatuses of security," the means by which the trilogy of sovereignty, discipline, and governmentality shape conduct. ${ }^{8}$ They include the military and police forces, intelligence agencies, and the health, welfare, and social systems. ${ }^{9}$

Governmentality theorists suggest that governing is the more or less deliberate attempt to direct behaviour of individuals targeted by a particular policy to bring about a particular result. Examples include public campaigns that warn of the risks associated with drink-driving or political rhetoric concerning the dangers inherent in boarding unsafe smugglers' boats, especially if travelling with children. Importantly, this shaping of conduct is moral in nature whereby government purports to know what behaviour is good and desirable and what behaviour is deviant. ${ }^{10}$

My research also considered the psychological impact of living under duress for extended periods of time, and how people overcome such experiences. These matters are briefly addressed in this article.

Participants' reasons for leaving Iraq, and the timing of their departures, varied. Some had fled or been forced out of Iraq by the ruling regime up to 20 years earlier, suspected of having Iranian antecedents at the time of the eight-year war between Iraq and Iran which started in 1980. Others had left Iraq in the aftermath of the 1991 uprisings in Iraq's south and the Kurdish north. The uprisings were brutally crushed by Saddam Hussein's regime which then sought retribution against its opponents. Some fled Iraq during the late 1990s after becoming of interest to Iraqi intelligence because of the actions of a father or brother or cousin; or because they refused to spy on colleagues or inform upon neighbours.

The countries of first asylum for participants were Iran, Jordan, or Syria. Of those who went to Iran, some made a decent life for themselves while others remained on the 
margins of society. In the late 1990s, Iranian authorities, struggling to cope with almost two million Afghan and Iraqi refugees, announced that it was time for people to go and started to withdraw work and other rights to reinforce that message. ${ }^{11}$

Neither Jordan nor Syria provided the safety or stability sought by the Iraqis. Even if they arrived legally, they lost that status as visas expired. They did not have work rights and struggled to survive. Jordan in particular was regarded as a place where onward travel was organized rather than offering a permanent home. ${ }^{12}$

As to why participants targeted Australia, in my study only a small number had friends or relatives living there. The majority followed the advice of smugglers; were influenced by cost when compared with journeys to Europe; or believed that as a Western country, Australia supported human rights and would provide sanctuary. The route to Australia for almost all involved a short sojourn in Malaysia, then to Indonesia with the intention of taking a boat to Australia.

\section{Indonesia as Host}

Indonesia is made up of over 17,000 islands of which 6,000 are inhabited. It is home to 240 million people and is the most populous Muslim nation. As well as contending with widespread poverty, corruption, and poor infrastructure across the islands, Indonesian authorities have had to address calls for independence from the populations of Papua, East Timor, and Aceh which have seen bloody confrontations between local militia and the powerful Indonesian military. ${ }^{13}$ The relationship between Indonesia and its closest southern neighbour, Australia, has been variable, with periods of cooperation interrupted by chilling of diplomatic relations, most noticeably with regard to Australia's support of East Timor at the time of its independence. ${ }^{14}$

Between 1979 and 1996, Indonesia had hosted refugee camps on the island of Galang for Indochinese refugees awaiting resettlement. When these closed there were very few refugees in the country. By the end of 1997, there were an estimated 100 refugees, mainly from the Middle East region. ${ }^{15}$ Yet between 1999 and 2001 about 13,000 refugees tried to reach Australia from Indonesia, of whom about 4,800 were Iraqi. This increase in refugee numbers had little to do with internal Indonesian politics, being instead a consequence of "push" factors in the Middle East region and growth in people-smuggling activity in Indonesia. There is no data to suggest that the relatively small numbers of refugees, most of whom transited Indonesia en route to Australia, were considered to be a risk factor for Indonesia given the size of its base population and the other priorities it had to address. Indonesia is not a signatory to the UN
Convention relating to the Status of Refugees (Refugees Convention), and at the time had not legislated to protect refugees. ${ }^{16}$

However, the presence of growing numbers of refugees in Indonesia was of concern to Australia, which had long demonstrated a reluctance to accept people arriving by boat on Australian shores asking for protection. Rather than being characterized as a humanitarian problem it was framed in terms of a risk to national and border security. In 2001, the Liberal Party-which was part of the Coalition government then in power-claimed that: ${ }^{17}$

The illegal movement of people poses a serious security and law enforcement challenge for Australia. People smuggling provides opportunities for the extension of international criminal activity, for the spread of terrorism, for the breakdown of law and order, and for the violation of laws which protect Australian health and security.

Fuelled by such rhetoric, public opinion in Australia was generally hostile to unauthorized boat arrivals. The Australian government instigated a number of measures to stop refugees reaching Australia by boat including a Regional Cooperation Agreement with the Indonesian government. This encouraged detention of asylum seekers by Indonesian authorities, aided by Australia's willingness to fund Indonesian detention facilities. ${ }^{18}$ Despite a change in government in Australia in 2007 and softening of the rhetoric, similar policies have continued as not to do so is politically risky for whichever government is in power, given the widespread antipathy to refugees and asylum seekers.

IOM, established in 1951, is an intergovernmental agency with over 120 member states. From December 1999 Australia contracted IOM to provide a range of migrationrelated services in Indonesia and other overseas locations, as part of its policy to prevent asylum seekers making their way to Australia. IOM in Indonesia has been involved in the monitoring and surveillance of those suspected of planning to travel to Australia to seek asylum as well as providing them with medical services, food and shelter, and assistance to return to their country of origin. ${ }^{19}$ This exemplifies how a sovereign power such as Australia utilizes external agencies to shape and influence the conduct of the objects of policy.

The Iraqi refugees in Indonesia were considered to be illegal immigrants if they did not have appropriate papers. If caught they were detained by Indonesian authorities and theoretically faced deportation. However, according to one commentator Indonesia did not have the funds to finance deportations, with the result that refugees stayed in detention. ${ }^{20}$ 
Generally, it was only intervention by UNHCR and subsequent registration with them that secured their release. As UNHCR resources were limited, refugees could be held for weeks in substandard accommodation before they were interviewed. When refugee claims were denied, applicants remained in detention indefinitely. ${ }^{21}$

An exception to this was made for hundreds of Middle Easterners, including Iraqis, who had been held in Indonesian immigration facilities for a number of years in the early 2000s. According to those interviewed by the author, without any explanation being proffered, between 2005 and 2007 they were moved to villas and hotels organized and overseen by IOM. Like those formally recognized as refugees by UNHCR in Jakarta they had no legal status in Indonesia and were not permitted to work. With few exceptions, their children were not able to attend schools. ${ }^{22}$ Refugees recognized as such by UNHCR were given a small allowance by UNHCR whereas others living in the community received an allowance from IOM.

In addition to the refugees who interacted with UNHCR and/or IOM, many others transited Indonesia without making contact with these agencies. Either they were kept hidden by their smugglers and had no such opportunity, or they were not interested in approaching UNHCR, having little faith in its ability to assist them as UNHCR-registered refugees stayed in Indonesia for years. ${ }^{23}$

\section{Participant Interviews and Accounts}

In late 2006 I interviewed Iraqi refugees who had been settled in Australia for a few years by that time. In early 2007 in Indonesia I interviewed Iraqis who had been living there in a limbo situation since before 2003; their numbers were being slowly augmented by new arrivals fleeing the Middle East region.

The fieldwork component was undertaken in the Cisarua/ Puncak area of Indonesia, about 100 kilometres south of the Indonesian capital of Jakarta. Although a popular tourist destination for wealthy Indonesians away from the stifling heat of the capital, it attracts few Western visitors. The refugees I met there were in a range of accommodation, with the majority living in small chalet-like homes in one of two compounds. One compound housed mainly Sabean Mandeans and the other was home mainly to Shia Muslims but also housed other nationalities such as Burmese. A number of men who had travelled alone-either single men or not accompanied by their families-lived in a nearby hotel.

In addition to conducting eight interviews, I met with a group of six men aged between 30 and 55 years, and spent many hours with participants and other Iraqis in social settings which were opportunities to gain further insights complementing the formal interviews. In all I spoke at length with about 30 Iraqis in Indonesia. When referring to or quoting participants below, pseudonyms have been used and I have avoided specifying medical conditions and naming professions that could lead to a participant being identified.

Of the eight interviews, four were conducted in people's homes, one in a café, two in communal gardens, and one in a television room used by the 40 or so residents living in the same complex. Five interviews required an interpreter. Without a working knowledge of Arabic, it was not possible for me to be sure of the quality of translation. However the responses as interpreted made sense given the questions I had asked, and at no time did the interpreter and participant appear to be engaging in a private conversation.

Generally, the Iraqis treated me hospitably, offering refreshments. The one occasion where I encountered direct hostility occurred when I met with the group of six men. The atmosphere was tense as they questioned me about what I was doing and why. They told me about another researcher who had disclosed information which created problems for them. It was evident that conducting interviews with these men was not appropriate but they did have opinions and views they wanted to convey, and they gave me permission to use these. This experience highlighted one of the many ethical challenges that can arise when conducting social research with marginalized and vulnerable groups. ${ }^{24}$

\section{Six Years and Counting ...}

Participants interviewed in Indonesia recounted why they, unlike the vast majority of Iraqis who had transited Malaysia and Indonesia en route to Australia, were still there. For some, their plans to reach Australia had been thwarted when they were caught by Indonesian authorities and imprisoned. A few ran out of money to pay smugglers or were unable to get a passage on a smugglers' boat before the trade all but finished in late 2001. Others preferred to register with UNHCR in the hope of being resettled. Some changed their minds about travelling on smugglers' boats to Australia after bad experiences on such boats. Taeseer was one, and recounted what happened to him and his family.

\footnotetext{
The boat journey was like death for twenty-four hours. There were twenty-one people on the boat which was a very small fishing boat and not big enough for twenty-one people. They put us on the bottom of boat. We lay down and they covered us with piece of wood maybe thirty centimetres from the ground. Then they put goods on top of that. We could not move. Nothing to eat, our little girl took milk. We sacrificed ourselves, all that trouble just for the future. The boat journey was in October when it was rainy and stormy. The smuggler chose bad weather as police don't patrol in bad weather and so wouldn't find us.
} 
Norres was one of a group of 23 Mandeans who, in October 2001, boarded a boat to Australia which came to be known as SIEV X. Alarmed by the overcrowding and the condition of the boat, the group disembarked while the boat was still close to the Indonesian shoreline. The following day SIEV X sank en route to Australia, killing 353 people, mainly Iraqi women and children. ${ }^{25}$ In Norres's words:

\footnotetext{
The waves were high. The boat began to break up, and water started to come in ... I was unconscious. I was sitting on the floor and behind me a piece of wood came loose. I was scared and thought I would fall into the sea. We smelt smoke and the bad smell of burning. It seemed as though we wouldn't arrive safely. We saw a fishing boat and called to them, and the twenty-three Mandeans left the boat.
}

The boat we had been on had sunk but we didn't know. We heard that the police captured it, then we heard that it sank, then we heard it arrived. We didn't know. We decided to try again to go to Australia. Then after two to three days we heard the news that the boat had definitely sank with very few survivors, maybe forty to forty five. Once we heard the news, we didn't want to try again.

\section{Fear and Insecurity; Anxiety and Powerlessness}

For all participants, whether interviewed in Indonesia or Australia, fear was a constant at all stages in their journey. It varied in intensity but was never absent. Some participants, especially the women, were reluctant to venture outside in Indonesia as their appearance and dress made them highly visible. Nezal was particularly frightened. "In Jakarta, we stayed in the hotel room for ten days. We were scared and worried in Indonesia." Nazek harboured similar fears. "We were afraid and in hiding, just waiting for the people smuggler to tell us what to do. We were like sheep. If told to gowe go. If told to stay-we stay."

A number of participants spoke of their fear of being incarcerated, having experienced prison in Iraq or seen the effect of Iraqi prisons on relatives. This fear was realized. All the participants based in Indonesia were locked up in Indonesian immigration detention facilities, of which there are a number across Indonesia of varying standards. Kokeb said that he and his family were arrested at their hotel on the day they arrived in Mendan, Indonesia, and spent 11 months in immigration detention, far away from UNHCR and IOM, which made it difficult to follow up on their cases. He said that although they were treated satisfactorily, the facility was unhygienic and many people became sick. Anness described a different facility in Jakarta which housed two to three hundred people where the conditions were very bad, with four or five persons or a single family to a room which was constantly checked. They were given little food and kept isolated.

No reason was given as to why Iraqi and other refugees in Indonesia were relocated from immigration detention centres after 2005 to better accommodation with greater freedom of movement and association. Anness doubted that concern for their welfare accounted for the change, believing instead it was simply to reduce pressure on the various authorities to find a permanent solution for them. It has not been possible to find any official explanation or reference to the changes. ${ }^{26}$

Despite these improved living conditions, participants still felt unsafe. Having been moved from detention centre to detention centre, and then into the community, with no explanation, they did not know for sure if they would be allowed to remain in Indonesia, under what conditions and what might happen next. The decisions affecting their longterm future were in the hands of UNCHR and the Australian and Indonesian governments. Control of their daily lives rested with these bodies and IOM. These contributed to their general sense of powerlessness over their lives.

In this regard, there was a sharp contrast with the accounts of the Iraqi refugees settled in Australia. At the time of their interviews, they had lived in Australia for five or so years, with the worst of their experiences behind them. While both groups spoke of the chronic fear they experienced during their journeys, those in Australia were recalling past events from which they had moved on; the Indonesia-based participants continued to live with the fear on a daily basis as their situation remained unresolved.

Indeed, it was clear that the issues of greatest significance to the Indonesia-based participants were their ongoing uncertainty and the years they felt had been wasted in Indonesia. They spoke of being pressured in the past by IOM to leave Indonesia and return to Iraq, and of being offered financial inducements to do so, but by 2007 this practice had largely stopped. For this reason, by the time I met them, they were not so concerned that they would be returned to Iraq against their will. However they spoke about ongoing anxiety and an inability to relax. They worried about family left behind, they worried about what the future might hold, they worried about how they would survive financially day to day, and they worried about the decisions they had made that had got them to where they were.

\section{Wasted Years}

Even though participants at the time of interviews were living in the community and could travel freely in the local area, they had to obtain permission to travel further afield and were not permitted to work. The denial of work rights affected participants on many levels. With support from 
UNHCR and IOM they received enough money to buy the basics but little else. Although their accommodation was secure, they lived in poverty. The lack of work rights was particularly distressing to participants who had the skills and desire to work. The professionals amongst them felt this keenly. Anness grieved for what his life could have been. After describing the obstacles he overcame to become qualified in his chosen profession and how hard he had studied, he said how wrong it was to deprive a person of the opportunity to put their skills to use.

Kokeb recounted how they passed their time. "We sit around. There is nothing to do. Sometimes we exercise, play games, use the computer or read books. We kill time as life continues." The standard of their accommodation and its location in a picturesque region of Indonesia was not enough to ameliorate the feelings of being trapped and powerless. As Gadeer said, "A bird in a beautiful cage is still in a cage."

Participants with families carried the burden of seeing their children suffer. Kokeb expressed his concern that children especially had been harmed by being held in Indonesian jails and detention centres. Like other parents, he was also worried of the lifelong impact on his children of missing out on the educational and social benefits of attending school. He had two children, both of whom had reached school age when they left the Middle East. After six years in Indonesia, he was anxious about their psychological health, particularly that of his daughter, who had few opportunities to socialize. He blamed himself, believing he had made mistakes in bringing his family to Indonesia where they faced a hopeless future, with his children paying for his mistakes.

Participants resettled in Australia recalled their experiences of Australian immigration detention centres and, upon release, of being issued with Temporary Protection Visa (TPVs) rather than their permanent equivalents. TPVs were introduced in late October 1999 for those recognized as refugees who had arrived in Australia without pre-arranged visas. TPV holders did not know if they would be allowed to remain in Australia. They could work but were not able to access facilities available to other refugees in Australia such as English classes and government assistance with finding employment. The harshest restrictions attached to TPVs related to family reunion and travel rights. Other refugees with permanent protection could apply for family members to join them, and were permitted to travel overseas and return to Australia. These rights were denied to TPV holders with the result that they were unable to be reunited with family, either in Australia or overseas, without losing the right to live in Australia. ${ }^{27}$
Participants in my study and other research ${ }^{28}$ spoke of the adverse effect that living with TPVs had on their psychological health. However their situation was arguably better than the refugees in Indonesia. TPV holders at least had work rights and were therefore able to occupy their time; plus they had more autonomy in managing their lives compared with those in limbo in Indonesia.

\section{Disillusionment with UNHCR and IOM}

Six of the eight participants interviewed in Indonesia expressed negative views towards UNHCR and IOM. The slow and opaque processing of asylum applications left participants perplexed and distressed by the different outcomes when all had fled Iraq and the Saddam regime. Taeseer said that his application for refugee status was rejected after his first interview and he was not told why. He said that he was still waiting for a response to an appeal he lodged before learning that the processing of Iraqi cases was put on hold in 2003 after the US invasion. Norres gave a similar account.

UNHCR interviewed us in February 2002. They reject us in April 2002. It never occurred to us that UNHCR would reject us. We were interviewed again in May 2002. There is still no result from that interview. In April 2006, they asked us to attend a new interview, so now we are waiting for the results from that interview.

Those found to be refugees were frustrated by UNHCR's failure to resettle them. "People are stuck in Indonesia. We are afraid to go back and cannot go forward. We are stuck in the middle," said Sabah. This was alarming for new arrivals. "When the new arrivals see the people who'd been in Indonesia for four years, they have no hope," he added. Anness recalled that when he, with others, demonstrated in front of UNHCR and IOM offices, the police were called to intervene and prevent journalists from talking with the refugees. Hadeel said he was effectively blackmailed by UNHCR staff who told him not to demonstrate or go on a hunger strike because if he did, Australia wouldn't help him, and that it would be better if the refugees accepted that life was unfair.

Their disillusionment with UNHCR went further than the body's inability to arrange settlement in a third country or work rights in Indonesia. Gadeer questioned its priorities.

The UNHCR office in Jakarta grows and improves. We think they are funded by Australia. UNHCR is supposed to be humanitarian but we see them to be a political organisation, in which case they are working for others and not helping asylum seekers find a solution. 
He, like many others, also suspected the politicization of UNHCR and IOM because they encouraged refugees to return to Iraq even though many Iraqi cities were unsafe.

As for resettlement in another country, this was unlikely as countries with resettlement programs were reluctant to take refugees they saw as Australia's responsibility, given that they had been intercepted en route to Australia, were physically close to Australia, and Australia funded both UNHCR and IOM in Indonesia. ${ }^{29}$ This caused additional frustration and despair. Hadeel said that he asked UNHCR to refer his case to Denmark where his sister and cousins lived but after a year was told that his only option was Australia although much later he was informed that his case would be put to Denmark. He said that even UNHCR staff regarded their situation as hopeless, telling the refugees they would be better off going with smugglers operating in Indonesia.

Participants had even greater misgivings about IOM than the UNCHR, feeling that the organization monitored their lives and restricted their freedom. Anness claimed that IOM watched them and reported upon them. He said that until 2004, IOM prevented them having contact with the outside world but their situation has since changed and the refugees can speak freely with journalists, researchers, and social workers.

\section{Resilience and Coping}

Time and again it became clear the participants attempted to ameliorate their situation in Indonesia. When they were moved to better accommodation, but provided with only mattress, blanket, and pillow, they acquired chairs, tables, and beds over the years. They attempted to set up classes and share their skills. They held demonstrations outside UNHCR offices and tried, without much success, to arrange regular meetings with it. Further, over time the different religious groups organized places where they could gather; the Shia now had a mosque, and the Mandeans had their own place.

Some of the men had married Indonesian women and had children. This, however, was tainted with great sadness, so much so I could not bring myself to explore it further with participants. As Anness told me "Many of the men have Indonesian wives now. Some men have left wives and kids at home. When families are split up, it's really painful to be separated for such a long time."

Anness spoke about how the refugees were supportive of each other. If they had problems between them, they resolved it themselves and avoided involving IOM in their disputes. He reflected that in the cramped detention environments where many people lived in one room for years, arguments inevitably occurred. These tended to be over food and access to the few toilets. He reflected that in the beginning, hopes of reaching Australia dominated people's thoughts. But as these hopes faded, they turned to making the best of their situation, recognizing that thinking about Australia all the time did them no good.

At various times, participants singly or in groups organized classes to pass on their skills. Taeseer said that between them, they had computer skills, English language and Arab literature. He said that they taught each other although the informal classes were mainly for the children. However, while sharing a meal with Anness and his family, I was told that, for a combination of reasons, the initiatives taken amongst the Iraqis to educate the children were not able to be sustained. Although they had knowledge of various subjects, they did not have material aids like books and blackboards, or venues to provide schooling to groups of children. In addition, both adults and children were worn out and depressed by their circumstances and attempts to school the children in any regular fashion faltered.

\section{The Ingredients of Feeling Safe}

It is well established that recovery from past trauma such as that typically experienced by people from a refugee background can only begin when people feel safe. ${ }^{30}$ Specifically, Steel et al. ${ }^{31}$ argue that a "sense of security ... seems to be essential for refugees to recover from trauma-related psychiatric symptoms" and that "insecure residency and associated fears of repatriation contribute to the persistence of psychiatric symptoms and associated disabilities."

One of the characteristics of the refugee experience is being caught up in events that are beyond the capacity of the individual to control. This may create a sense of powerlessness and shatter a person's belief in their ability to manage their own lives. It points to the importance of building self-efficacy and self-empowerment as part of the recovery process in the aftermath of experiencing extreme events. ${ }^{32}$ Family also plays a crucial role in the recovery process. While a person is worrying about their family, they are less likely to have the internal resources to tend to their own needs. Conversely recovery is impeded if there are fears about the well-being of family members. A recent study conducted with Iraqi refugees settled in Australia found that their concerns for the safety of family still in Iraq had a significant impact on the severity of post-traumatic stress disorder, anxiety, and depression. ${ }^{33}$

Employment is another critical element in regaining hope for their future. ${ }^{34}$ Practically, it means an income which can pay for accommodation and buy possessions. It also provides routine and stability, and builds a sense of competence and self-worth. It allows a person the satisfaction of knowing they are providing for self and family. It 
also connects people to their community and can be the base for new social networks. It occupies the mind, providing a positive distraction from memories of events of the past. ${ }^{35}$ In this fashion, employment contributes to a feeling of being safe and secure, necessary for the healing from trauma to occur.

Hobfoll et al. ${ }^{36}$ make the point that unless people who have been through extreme adversity feel safe, have the means to start rebuilding their lives, and are able to establish control over their daily lives, psychological interven tions have little benefit. Almedom and Summerfield ${ }^{37}$ sum up the situation perfectly:

How people recover from catastrophe is a profound question, but the lessons of history are straightforward: "recovery" is not a discrete process. It happens in people's lives rather than their psychologies. It is practical and unspectacular, grounded in the resumption of the ordinary rhythms of everyday life-familial, sociocultural, religious and economic activities that make the world intelligible.

\section{The Situation of Participants}

Rather than being given the tools to build self-efficacy and self-reliance, participants based in Indonesia had few opportunities to exert control over their own lives. They had all spent years detained in immigration detention facilities before being moved to hotels or villas. The small allowance they were given to buy food was barely adequate but they were not allowed to work to augment it. If they needed medical attention they were reliant on IOM. The inability to provide adequately for themselves and their families was particularly hard for the men, traditionally the providers. Without money or a job, each day was the same, with no hope for improvement or change. The lack of work rights was a major contributor to boredom and depression. Many participants felt that fruitful years of their lives were simply going to waste. Those with professional training feared losing the skills they had acquired along with any hope of resurrecting their careers. Single men were concerned they were missing the opportunity to find wives and start families. Those who had left their families behind in the Middle East had no means to support them from afar or be reunited, while those who had travelled with their families saw their children becoming depressed and shamed because of the lack of schooling and opportunity. This left the men troubled by guilt, feeling it was their decisions that had placed their families in this situation.

Further, participants had no idea how long they would be in that situation, and indeed, if it would ever improve. Those who had been unsuccessful with their applications to UNHCR for refugee status and resettlement would reapply. Steel et al. ${ }^{38}$ point out that refugee claimants can be retraumatized by retelling their story, especially in a formal setting and under questioning where any challenge to their credibility can have a deleterious effect on mental health.

The normal and natural response for people facing stressful conditions is to use their own resources and abilities to try and improve their situation. ${ }^{39}$ Generally, the participants warehoused in Indonesia did this. However they were faced with socio-political realities that left them feeling vulnerable and insecure. The solution to their stress and anxiety lay in the simple expedient of allowing them to live without the fear of physical harm, a permanent home, family reunion, work rights, and education for their children but for many years this was denied them.

\section{Concluding Thoughts}

Participants in both Indonesia and Australia voiced similar sentiments concerning their years of uncertainty and insecurity and the adverse effect these had on their psychological well-being. Their narratives clearly indicate that refugee populations through no fault of their own find themselves to be largely powerless and at the mercy of those in positions of power. The Australian government, with its access to extensive resources, sought to minimize its political risk by using a variety of means to stop asylum seekers reaching Australian shores and deterring others from attempting that journey even though these means increased the risk to the asylum seekers in the following ways. Their physical and mental health was put at risk because of years of incarceration, uncertainty, living in poverty, and, for many, separation from families left behind. With almost no legitimate means of finding permanent refuge, many refugees bought passages on smugglers' boats and some of those lost their lives in the seas between Indonesia and Australia. IOM, at the behest of the Australian government, encouraged Iraqis to return to home despite the uncertain security situation there. The Australian government painted the asylum seekers as deviant to justify policy responses ${ }^{40}$ and to varying degrees suborned other bodies such as UNHCR, IOM, and the Indonesian government to its own interests. These bodies then operated, using Foucault's nomenclature, as apparatuses of security for the Australian government.

Pat O'Malley, ${ }^{41}$ who has written extensively on risk, argued that although the technology of risk is generally regarded negatively by liberal scholars and proponents of social justice, the adoption of a risk analytic to address a social problem could be productive. He suggested that such an approach allows framing an issue differently, involving the objects of policy in the development of it, and de-emphasising binaries such as victim/offender, powerful/powerless, 
expert/layperson. Together these promote a different way of thinking, a different set of questions and hence a different set of answers.

In considering O'Malley's reasoning as it might be applied to Australian refugee policy, it would begin by canvassing all identifiable and relevant risks-border and national security concerns and risks to the health and well-being of asylum seekers-and seek to quantify them. Questions framed in terms of risk sidestep value-laden concerns, instead emphasizing preferred outcomes which can be agreed by stakeholders and assessed against indicators that include, perhaps, human rights instruments as well as numbers of unauthorized boat arrivals. Being risk-focused, questions would consider damage that might be done to, for example, Australia's standing overseas if seen to be in breach of international law as well as those most directly affected by the policy. This approach would look at the financial costs of contracting out to service providers such as IOM, and financing the building and refurbishment of Indonesian immigration detention centres, and weighing these against the financial cost of alternative policies. These might have a different aim altogether or seek to stop asylum seekers getting on smugglers' boats by providing them with an attractive alternative rather than prevention through detention.

Adopting a risk-based approach in a comprehensive fashion is, then, more measured and ultimately pragmatic. It has the potential to facilitate finding a solution to the dilemma that confronts those policy makers who may believe that a humanitarian/human rights approach to refugees is desirable but feel constrained by the politics of the day.

\section{Notes}

1. Sue Hoffman, "Fear, Insecurity and Risk: Refugee Journeys from Iraq to Australia" (PhD diss., Murdoch University, 2010), accessible http://researchrepository.murdoch.edu .au/4459/.

2. For discussions on grounded theory, see Pamela Clark, Sally Thigpen, and Amy Yates, "Integrating the Older/ Special Needs Adoptive Child into the Family," Journal of Marital and Family Therapy 32 (2006): 181-95; Yun-Hee Jeon, "The Application of Grounded Theory and Symbolic Interactionism," Scandinavian Journal of Caring Sciences 18 (2004): 249-56; Tara Kennedy and Lorelei Lingard, "Making Sense of Grounded Theory in Medical Education," Medical Education 40 (2006): 101-8.

3. Ulrich Beck, "Living in the World Risk Society," Economy and Society 35 (2006): 329-45.

4. Dilip Hiro, Iraq in the Eye of the Storm (New York: Thunder's Mouth Press, 2002).
5. Ulrich Beck, "Risk Society Revisited: Theory, Politics and Research Programmes," in The Risk Society and Beyond: Critical Issues for Social Theory, ed. Barbara Adam, Ulrich Beck, and Joost Van Loon (London: Sage Publications, 2000).

6. Alan Nichols, "On Foucault and the Genealogy of Governmentality” (PhD diss., University of Missouri, Columbia, 2007).

7. See Patricia Harris, "Public Welfare and Liberal Governance," in Poststructuralism, Citizenship and Social Policy. ed. Alan Petersen, Ian Barns, Janice Dudley, and Patricia Harris (London: Routledge, 1999). Michel Foucault, "The Subject and Power," in Foucault, Beyond Structuralism and Hermeneutic, ed. Hubert Dreyfus and Paul Rabinow (Brighton: Harvester Press, 1982).

8. Dave Holmes and Denise Gastaldo, "Nursing as Means of Governmentality," Journal of Advanced Nursing 38 (2002): 557-65.

9. See Mitchell Dean, Governmentality: Power and Rule in Modern Society (London: Sage Publications, 1999).

10. Ibid.

11. Ruben Zaiotti, "Dealing with Non-Palestinian Refugees in the Middle East: Policies and Practices in an Uncertain Environment," International Journal of Refugee Law 18 (2006): 333-53.

12. Geraldine Chatelard, "Jordan as a Transit Country: Semiprotectionist Immigration Policies and Their Effects on Iraqi Forced Migrants" (Working Paper 61, New Issues in Refugee Research, Robert Schuman Centre for Advanced Studies, European University Institute, Florence, Italy, 2002).

13. John T. Sidel, Indonesia: Minorities, Migrant Workers, Refugees, and the New Citizenship Law (Geneva: United Nations High Commissioner for Refugees, 2007), 1-2.

14. Allan Gyngell, "Australia-Indonesia," in Australia as an Asia Pacific Regional Power: Friendships in Flux? ed. Brendan Taylor (New York: Routledge, 2007), 97-116.

15. “Country Report Indonesia 1998," U.S. Committee for Refugees and Immigrants, accessed February 14, 2009, http://www.refugees.org/countryreports.aspx?id=960.

16. Hoffman, Fear, Insecurity and Risk, 193.

17. "The Howard Government: Putting Australia's Interests First, Election 2001: Protecting Our Borders," Liberal Party of Australia, accessed February 21, 2006, http://www .ozpolitics.info/election2004/2001LNP/border-protection -policy.pdf.

18. Ibid.

19. "Financial Report for the Year Ended 31 December 2007," International Organization for Migration, accessed August 9, 2008, http://www.iom.int/jahia/webdav/shared/shared/ mainsite/about_iom/docs/financial_report_2007.pdf.

20. Tim Lindsey, “Too Prosperous?' Indonesian Responses to Australian Asylum-Seeker Policies," (Working paper, Asian Law Centre, Melbourne Law School, University of 
Melbourne), accessed September 23, 2009, http://www.law .unimelb.edu.au/icil/whats\%2Don/tampa/tlindsey.html.

21. For an overview of refugee protection in Indonesia, see Savitri Taylor, "Seeking an Alternative to Life in Limbo," Inside Story (2009), accessed March 5, 2012, http://inside .org.au/seeking-an-alternative/.

22. "By Invitation Only: Australian Asylum Policy," Human Rights Watch (2002), accessed July 14, 2011, http://www .hrw.org/en/reports/2002/12/10/invitation-only.

23. Ibid.

24. For a discussion of ethical issues that arise when conducting research with refugees, see Karen Jacobsen and Loren Landau, “The Dual Imperative in Refugee Research: Some Methodological and Ethical Considerations in Social Science Research on Forced Migration," Disasters 3 (2003): 185-206. For a fuller account of the ethical issues that arose during my research, see Hoffman, Fear, Insecurity and Risk, 75-80.

25. Marg Hutton, "SIEVX Chronology," Sievx.com, accessed July 17, 2011, http://www.sievx.com/chronology/.

26. I have been unable to find any official explanation for these changes or, indeed, any official acknowledgement that they occurred. Participants did not attribute the changes to any specific event such as the 2003 invasion of Iraq. Only one participant referred to that, and in the context of refugee applications being put on hold, mirroring what occurred in Australia where, in 2003, a moratorium was placed on the processing of applications for permanent protection in the expectation that the situation in Iraq would improve and Iraqis seeking protection could be sent home.

27. Linda Briskman et al., Human Rights Overboard (Melbourne: Scribe Publications, 2008), 330.

28. Michael Leach and Feithi Mansouri, Lives in Limbo (Sydney: UNSW Press, 2004). Also Greg Marston, “The not-sospecial benefit and non-mutual obligation: refugees on a TPV and income support arrangements" (paper presented at Refugee Rights Symposium, Critical Perspectives on Refugee Policy in Australia, hosted by the Institute for Citizenship and Globalisation, Faculty of Arts, Deakin University, December 2002.)
29. "By Invitation Only," 59.

30. Stevan Hobfoll et al., "Five Essential Elements of Immediate and Mid-Term Mass Trauma Intervention: Empirical Evidence," Psychiatry 4 (2007): 283-315.

31. Zachary Steel et al., "Impact of Immigration Detention and Temporary Protection on the Mental Health of Refugees," British Journal of Psychiatry 188 (2006): 64.

32. Hobfoll et al, "Five Essential Elements."

33. Angela Nickerson et al., "The Impact of Fear for Family on Mental Health in a Resettled Iraqi Refugee Community," Journal of Psychiatric Research 4 (2010): 229-35.

34. Hobfoll et al, "Five Essential Elements," 299.

35. Frances McKee-Ryan et al., "Psychological and Physical Well-Being during Unemployment: A Meta-Analytic Study," Journal of Applied Psychology 1 (2005): 53-76.

36. Hobfoll et al, "Five Essential Elements," 299.

37. Astier M. Almedom and Derek Summerfield, "Mental Well-Being in Settings of 'Complex Emergency': An Overview," Journal of Biosocial Science 4 (2004): 386.

38. Zachary Steel et al., "Part I-The Mental Health Impacts of Migration: The Law and Its Effects. Failing to Understand: Refugee Determination and the Traumatized Applicant," International Journal of Law and Psychiatry 27 (2004): 511-28.

39. Derek Summerfield, "Cross Cultural Perspectives on the Medicalisation of Human Suffering," in Posttraumatic Stress Disorder: Issues and Controversies, ed. Gerald Rosen, (Hoboken, New Jersey: Wiley, 2004), 233-46.

40. Sharon Pickering, Refugees and State Crime (Sydney: Federation Press, 2005).

41. Pat O'Malley, "Experiments in Risk and Criminal Justice," Theoretical Criminology 12 (2008): 451-69.

Sue Hoffman is an honorary research associate at Murdoch University, Perth, Western Australia. Her primary research interests focus on asylum seekers and people smuggling in the Australian context. 